Sosa-Cornejo, I., Martín-del-Campo, R., Contreras-Aguilar, H. R., Enciso-Saracho, F., González-Camacho, Z. B., Guardado-González, J. I., Campista-Leon, S., \& PeinadoGuevara, L. I. (2021). Nesting trends of olive ridley sea turtles Lepidochelys olivacea (Testudinata: Cheloniidae) on two beaches in Northwestern Mexico after 30 and 40 years of conservation. Revista de Biología Tropical, 69(3), 11241137. https://doi.org/10.15517/rbt.v69i3.46490

\title{
Nesting trends of olive ridley sea turtles Lepidochelys olivacea (Testudinata: Cheloniidae) on two beaches in Northwestern Mexico after 30 and 40 years of conservation
}

Ingmar Sosa-Cornejo ${ }^{1,2}$; iD https://orcid.org/0000-0003-0465-9956

Rodolfo Martín-del-Campo3; (iD https://orcid.org/0000-0002-7280-3932

Héctor R. Contreras-Aguilar ${ }^{4 *}$; (D) https://orcid.org/0000-0003-3879-3643

Fernando Enciso-Saracho5; (D) https://orcid.org/0000-0002-2847-9055

Zuleika Beatriz González-Camacho²; (D) https://orcid.org/0000-0003-3110-2918

Jesus I. Guardado-González ${ }^{6}$; (DD https://orcid.org/0000-0002-0257-6826

Samuel Campista-Leon ${ }^{7}$; (D) https://orcid.org/0000-0001-7552-2303

Luz I. Peinado-Guevara ${ }^{7}$; (D) https://orcid.org/0000-0001-5881-4558

1. Posgrado en Ciencias Biológicas, Facultad de Biología, Universidad Autónoma de Sinaloa, Culiacán, Sinaloa, México; parlamamichin@uas.edu.mx

2. Laboratorio de Tortugas Marinas, Facultad de Biología, Universidad Autónoma de Sinaloa, Culiacán, Sinaloa, México; zulegoncam@gmail.com

3. Department of Oral Health Sciences, Faculty of Dentistry, Life Sciences Institute, University of British Columbia, Vancouver, BC V6T 1Z3, Canada; rodolfo@dentistry.ubc.ca

4. Programa de Tortugas Marinas de la Unidad Académica Preparatoria "Comandante Víctor Manuel Tirado López", Universidad Autónoma de Sinaloa, Rosario, Sinaloa, México; contrerasaguilarhector@gmail.com (*Correspondence)

5. Programa de Tortugas Marinas de la Facultad de Ciencias del Mar, Universidad Autónoma de Sinaloa, Mazatlán, Sinaloa, México; mano24@live.com

6. Departamento de Turismo, H. Ayuntamiento de Elota, Sinaloa, México; ivantortugasceuta1@gmail.com

7. Laboratorio de Microbiología y Biología aplicada, Facultad de Biología, Universidad Autónoma de Sinaloa, Culiacán, México; samcl@uas.edu.mx,luzipg@uas.edu.mx

Received 31-III-2021. C Corrected 07-VI-2021. Accepted 19-IX-2021.

\begin{abstract}
Introduction: Although olive ridley sea turtle (Lepidochelys olivacea) are the most abundant sea turtles in the world, quantitative information is scarce and unevenly distributed among regions. There are many management and conservation programs for this species, and assessments are necessary to identify nesting trends and effectively manage current conservation programs. PROTORMAR-UAS is a Research and Conservation program for the olive ridley turtle created by the Autonomous University of Sinaloa, Mexico. The program utilizes two biological stations: Santuario Playa Ceuta (SPC) and Playa Caimanero (PC).

Objective: To evaluate the nesting trend of olive ridley turtles on two beaches in Northwestern Mexico and to predict prospective nesting trends for the next 30 years.

Methods: Using annual nesting data collected over 40 years at SPC (1976-2016) and 30 years at PC (19862016), we evaluated nesting trends, hatching success, predation and poaching of olive ridley turtles on the two beaches in Northwestern Mexico. Then, prospective nesting estimates for the next 30 years were calculated predictive time series model.
\end{abstract}


Results: A positive and significant correlation was identified between the number of annual nests and time for both beaches ( $r$ o $=0.850, \mathrm{P} \leq 0.01$ for $\mathrm{SPC}$; rho $=0.677, \mathrm{P} \leq 0.01$ for $\mathrm{PC}$ ); the average hatching success rates were 65.09 at SPC and $60.72 \%$ at PC. The predictive time-series model indicated that the numbers of nests will continue to increase through 2045, increasing three-fold at SPC and six-fold at PC with respect to the last year of monitoring.

Conclusions: There was a clear positive trend in the number of olive ridley sea turtle nests at both sites, which is consistent with trends found in other recent studies from the region. Therefore, we suggest that PC be designated a legally protected nesting area since it is located within the latitudinal limits of olive ridley nesting and given the need for resources for camp operation considering increased nesting and current problems with predation and poaching. Because in Mexico operating a nesting beach without any protection status implies not having a budget for its management.

Key words: nests; sea turtle conservation; olive ridley turtle; hatching success; poaching and predation.

Nesting and feeding habitats of six of the seven species of sea turtles in the world are distributed in Mexico, and sea turtle migratory corridors include coastlines with national jurisdiction (Márquez, 1990). Sea turtles and humans have interacted for thousands of years, and sea turtles have been a source of food since the beginning of the first civilizations, including in ancient Mesopotamia (Frazier, 2003). In Mexico, sea turtle harvesting started in the late 1950 s and early 1960 s, and it is estimated that between 1965 and 1970, more than 2 million sea turtles (mostly olive ridleys) were captured (Márquez, 1996; Peñaflores et al., 2000). This practice, together with other human activities such as egg extraction, destruction of habitats in nesting areas, and bycatch, has had an impact on the decline in sea turtle populations (Behera et al., 2016; Pandav et al., 1998; Pritchard, 1996; Spotila, 2004); therefore, in 1966, the first turtle camps for study and conservation were established, and in 1990, a total and permanent ban of the capture of all species of sea turtles in Mexico was declared (DOF, 1990).

The olive ridley sea turtle (Lepidochelys olivacea) is considered the most abundant sea turtle in the world, and its main nesting sites occur on the East coast of India and the coasts in the Eastern Pacific, mainly in Costa Rica and Mexico (Abreu-Grobois \& Plotkin, 2008). This species nests between July and January, with two nesting strategies: solitary and "arribada"; the latter is a unique nesting strategy of the genus Lepidochelys in which thousands of females arrive to nest synchronously on specific beaches for several days (Márquez, 1990; Pritchard, 2007). In Mexico, solitary nesting areas extend from the coast of Baja California Sur to the coast of Chiapas (CONANP, 2011). Currently, Mexican legislation considers this species "endangered" (DOF, 2010); it remains "vulnerable" according to the red list of threatened species of the International Union for the Conservation of Nature (IUCN) (AbreuGrobois \& Plotkin, 2008) and is included in Appendix I of the Convention on International Trade in Endangered Species (CITES, 2014).

Because olive ridley sea turtles do not reach sexual maturity until approximately 13 years (8-18 years) of age (Márquez, 1996; Zug et al., 2006), assessments of nesting trends over time are necessary to implement actions and effectively manage current conservation programs (Richardson, 2000). At Playa Escobilla, the most important arribada beach in Mexico, sustained recovery has been reported, with an increase from 200000 nests in 1990 to more than one million nests in 2010 (CONANP, 2011); however, evaluations on solitary beaches are rare (Ariano-Sánchez et al, 2020; da Silva et al., 2007; Hart et al., 2018; James \& Melero 2015; Viejobueno Muñoz \& Arauz, 2015). Evaluations at nesting beaches are necessary to identify current nest trends, predict future outlooks and make appropriate management and conservation decisions for the benefit of the population of sea turtle under study (Balazs \& Chaloupka, 2006; Ceriani et al., 2019; Honarvar et al., 2016). 
The Autonomous University of Sinaloa (UAS) began efforts to conserve and conduct research on sea turtles, and in 1976, it implemented the Sea Turtle Program (PROTORMAR-UAS), with the commitment to protect, conserve and research these species as well as their habitats. The program utilizes two biological stations, Santuario Playa Ceuta (SPC) and Playa Caimanero (PC), and continuous annual data on nest abundance and hatching success (HS) as well as problems such as poaching and nest predation have been collected. The objective of this study was to evaluate the nesting trends of olive ridley turtles at two beaches in Northwestern Mexico (40 years for SPC and 30 for PC) and to predict prospective nesting success over the next 30 years.

\section{MATERIALS AND METHODS}

Study site: The study was conducted on two nesting beaches: SPC and PC. SPC is $37 \mathrm{~km}$ long and is located between the Cospita Estuary to the North $\left(23^{\circ} 05^{\prime} 40^{\prime \prime} \mathrm{N}\right.$ \& $\left.107^{\circ} 11^{\prime} 42^{\prime \prime} \mathrm{W}\right)$ and the Elota River to the
South (2352'43" N \& $\left.106^{\circ} 55^{\prime} 51^{\prime \prime} \mathrm{W}\right)$; it is in the central region of the state of Sinaloa, Mexico, in the municipality of Elota (Fig. 1). SPC was declared a Reserve and Refuge Zone for the Protection, Conservation, Repopulation, Development and Control of Various Species of Sea Turtles (DOF, 1986) and as a sanctuary for olive ridley turtle nesting (CONANP, 2018; DOF, 2002). PC was designated a biological station in 1986; it is approximately $39 \mathrm{~km}$ long and is located between the mouth of the Presidio River to the North $\left(23^{\circ} 05^{\prime} 29^{\prime \prime}\right.$ N \& $\left.106^{\circ} 17^{\prime} 19^{\prime \prime} \mathrm{W}\right)$ and the mouth of the Baluarte River to the South $\left(22^{\circ} 50^{\prime} 15^{\prime \prime}\right.$ N \& $106^{\circ} 02^{\prime} 26^{\prime \prime}$ $\mathrm{W})$; it is in the Southern region of the state of Sinaloa, Mexico, in the municipality of Rosario (Fig. 1). PC is not yet legally designated as a protected beach.

Nesting data: During the nesting season (July-December) from 1976 to 1991 at SPC and from 1986 to 1991 at PC, night tours were carried out by university staff and field volunteers to collect eggs and conduct a census of nests (collected, poached and predated); however,
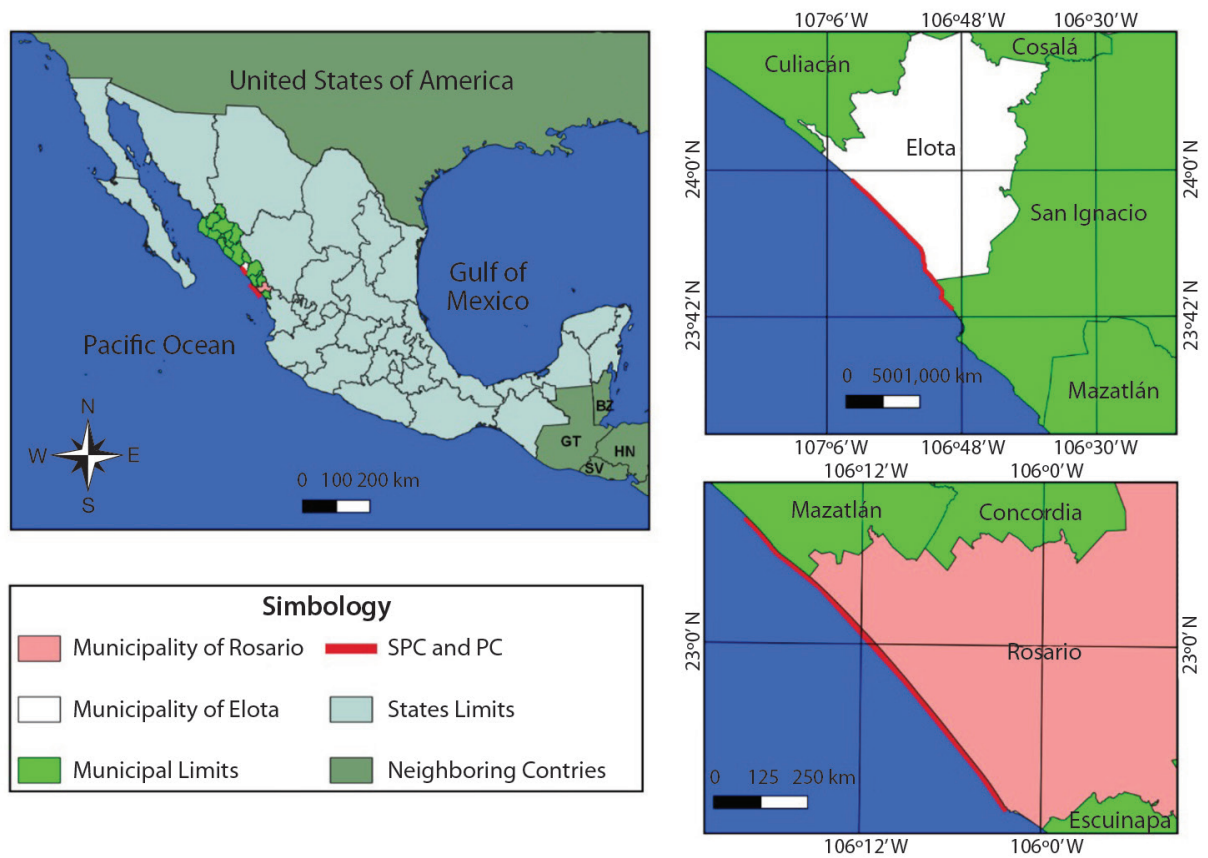

Fig. 1. Location of the nesting beaches of Lepidochelys olivacea in Northwestern Mexico managed by PROTORMAR-UAS. 
during this period, it was not possible to cover the entire beach on a daily basis due to logistical and budget reasons. In 1992, more personnel and transport equipment were obtained, and the tours were carried out systematically. The tours 1) followed daily routes and 2) covered the entire study area, ensuring the counting of all nests in each season (Schoreder \& Murphy, 2000). The collected eggs were incubated in hatchery or polyurethane boxes that were numbered consecutively to facilitate analysis (Mortimer, 1999). At the end of the incubation period, nest exploration was performed (45 \pm 3 days) to estimate hatching success (HS) by dividing the number of eggs hatched (NEH) by the total number of eggs (TNE) incubated for each nest, with the formula $\mathrm{HS}=(\mathrm{NEH} / \mathrm{TNE})$ $\times 100$ (Caut et al., 2006). Later, the hatchlings were released into the sea during the night or at dawn during low tide when the waves were not very strong so the hatchlings could enter the sea easily and quickly, preventing predation. This research was carried out under agreements with and permits granted by the Subsecretaria de Gestión para la Protección Ambiental, Dirección General de Vida Silvestre (SGPA/ DGVS/06306), which are renewed annually.

Data analysis: The total number of nests for each season, including collected, predated and poached nests, the HS for each beach each year were collected. The averages (with their standard deviations) of each of these parameters for the entire period were calculated, and a Mann-Whitney $\mathrm{U}$ test $(\mathrm{P}<0.05)$ was performed to identify differences between the beaches with respect to the monitoring data. Spearman correlation analysis was used to assess correlations between the total nests registered (which included collected, predated and poached nests) and the study period. All statistical analyses were performed with SigmaPlot v11 software. Nest abundance in 2045 was predicted by a predictive time series model using IBM SPSS Statistics 23 software (Brown et al., 1975; Gil \& Lobo, 2012). The prospective analysis was performed for the next 30 years (more than two generations) considering the average age at sexual maturity (13 years) of the olive ridley turtle (Márquez, 1996; Zug et al., 2006), with the assumption that mortality will remain constant due to the standardization of the years that PROTORMAR-UAS has performed work on the beaches.

\section{RESULTS}

Registered and collected nests and predation and poaching: At SPC from 1976 to 2016, a total of 11238 nests were registered, of which 9755 were collected, 848 were predated, and 635 were poached (Table 1); at this beach, before 1992, the collection of nests was variable (mean $=99.4 \pm 75.4$ nests per year). This was because the same effort was not made for technical reasons, but in 1992, the effort was standardized, and since then, the number of nests was approximately $340.2 \pm 164$ nests/ year, although there were nesting seasons with less than 200 nests/year $(1995=187,1998=$ $186,2001=169,2002=157$ and $2003=188)$. In 2004 , it was not possible to work due to budget constraints. At PC, only data from 1989 to 2016 were considered event though protection began in 1986; before 1989, there were technical and operational difficulties preventing consistent monitoring, and some data were lost. During the study period a total of 29001 nests were registered, of which 24379 were collected, 1878 were predated and 2744 were poached. The average number of registered nests before 2005 was $176.9 \pm 110.1$ nests/year, and after 2005 , the abundance of nests increased to $2180.9 \pm 1144.6$ nests/year. The 2015 season had the highest nesting record (4 859 nests) (Table 1). When comparing the parameters between nesting beaches, no significant differences were identified $(\mathrm{P}>0.05)$.

Nesting, predation, and poaching trends: For both nesting beaches, a positive and significant correlation was observed between the number of registered nests and time (rho $=0.850, \mathrm{P} \leq 0.01$ for $\mathrm{SPC}$, rho $=$ $0.677, \mathrm{P} \leq 0.01$ for $\mathrm{PC}$, Table 2) and between predated nests and time $(\mathrm{rho}=0.454, \mathrm{P}=0.003$ 
TABLE 1

Annual data on nests and eggs collected as well as predation and poaching of olive ridley turtle (Lepidochelys olivacea) nests in Santuario Playa Ceuta (1976-2016) and Playa Caimanero (1989-2016)

\begin{tabular}{|c|c|c|c|c|c|c|c|c|c|c|}
\hline \multicolumn{6}{|c|}{ Santuario Playa Ceuta } & \multicolumn{5}{|c|}{ Playa Caimanero } \\
\hline Years & $\begin{array}{l}\text { Registered } \\
\text { nest }\end{array}$ & $\begin{array}{c}\text { Collected } \\
\text { nests }\end{array}$ & $\begin{array}{l}\text { Protected } \\
\text { eggs }\end{array}$ & $\begin{array}{l}\text { Predated } \\
\text { nests }\end{array}$ & $\begin{array}{c}\text { Poached } \\
\text { nests }\end{array}$ & $\begin{array}{l}\text { Registered } \\
\text { nest }\end{array}$ & $\begin{array}{c}\text { Collected } \\
\text { nests }\end{array}$ & $\begin{array}{l}\text { Protected } \\
\text { eggs }\end{array}$ & $\begin{array}{c}\text { Predated } \\
\text { nests }\end{array}$ & $\begin{array}{c}\text { Poached } \\
\text { nests }\end{array}$ \\
\hline 1976 & 84 & 40 & 4013 & 14 & 30 & & - & - & & \\
\hline 1977 & 129 & 112 & 11414 & 12 & 5 & & - & - & & \\
\hline 1978 & 104 & 75 & 7646 & 8 & 21 & & - & - & & \\
\hline 1979 & 65 & 48 & 4993 & 5 & 12 & & - & - & & \\
\hline 1980 & 39 & 35 & 3696 & 4 & 0 & & - & - & & \\
\hline 1981 & 52 & 47 & 4774 & 5 & 0 & & - & - & & \\
\hline 1982 & 46 & 35 & 3476 & 4 & 7 & & - & - & & \\
\hline 1983 & 72 & 47 & 4993 & 4 & 21 & & - & - & & \\
\hline 1984 & 82 & 65 & 4858 & 0 & 17 & & - & - & & \\
\hline 1985 & 67 & 51 & 6448 & 5 & 11 & & - & - & & \\
\hline 1986 & 125 & 104 & 10631 & 14 & 7 & & - & - & & \\
\hline 1987 & 208 & 179 & 15720 & 23 & 6 & & - & - & & \\
\hline 1988 & 222 & 197 & 18336 & 25 & 0 & & - & - & & \\
\hline 1989 & 61 & 61 & 6076 & 0 & 0 & 124 & 117 & 11710 & 1 & 6 \\
\hline 1990 & 286 & 241 & 25441 & 31 & 14 & 294 & 277 & 27456 & 3 & 14 \\
\hline 1991 & 300 & 253 & 24441 & 32 & 15 & 205 & 193 & 18351 & 2 & 10 \\
\hline 1992 & 305 & 243 & 23913 & 38 & 24 & 325 & 307 & 28716 & 3 & 15 \\
\hline 1993 & 294 & 240 & 30047 & 21 & 33 & 187 & 176 & 15853 & 2 & 9 \\
\hline 1994 & 371 & 301 & 22040 & 28 & 42 & 203 & 191 & 18669 & 2 & 10 \\
\hline 1995 & 251 & 187 & 14930 & 9 & 55 & 165 & 155 & 14046 & 2 & 8 \\
\hline 1996 & 294 & 225 & 20923 & 20 & 49 & 394 & 371 & 35348 & 4 & 19 \\
\hline 1997 & 348 & 343 & 30785 & 2 & 3 & 318 & 300 & 29111 & 3 & 15 \\
\hline 1998 & 194 & 186 & 13190 & 2 & 6 & 145 & 137 & 13052 & 1 & 7 \\
\hline 1999 & 237 & 219 & 24069 & 7 & 11 & 129 & 122 & 11168 & 1 & 6 \\
\hline 2000 & 251 & 224 & 22159 & 3 & 24 & 57 & 53 & 5026 & 1 & 3 \\
\hline 2001 & 196 & 169 & 18474 & 8 & 19 & 30 & 28 & 2873 & 1 & 1 \\
\hline 2002 & 169 & 157 & 12290 & 4 & 8 & 152 & 144 & 13470 & 1 & 7 \\
\hline 2003 & 208 & 188 & 19166 & 18 & 2 & 12 & 10 & 903 & 1 & 1 \\
\hline 2004 & - & - & - & - & - & 90 & 85 & 8081 & 1 & 4 \\
\hline 2005 & 246 & 239 & 26872 & 3 & 4 & 781 & 737 & 67262 & 7 & 37 \\
\hline 2006 & 361 & 319 & 27649 & 11 & 31 & 1288 & 1215 & 104558 & 12 & 61 \\
\hline 2007 & 398 & 388 & 35176 & 3 & 7 & 1815 & 1712 & 151899 & 17 & 86 \\
\hline 2008 & 536 & 467 & 40470 & 43 & 26 & 1813 & 1710 & 153394 & 17 & 86 \\
\hline 2009 & 462 & 392 & 23673 & 39 & 31 & 1415 & 1335 & 101560 & 13 & 67 \\
\hline 2010 & 531 & 472 & 35413 & 45 & 14 & 1416 & 1336 & 124291 & 13 & 67 \\
\hline 2011 & 403 & 353 & 24994 & 44 & 6 & 2108 & 1449 & 127723 & 232 & 427 \\
\hline 2012 & 565 & 495 & 36830 & 56 & 14 & 3070 & 2110 & 198991 & 338 & 622 \\
\hline 2013 & 473 & 398 & 37854 & 70 & 5 & 3332 & 2290 & 218051 & 366 & 676 \\
\hline 2014 & 680 & 640 & 55667 & 16 & 24 & 2814 & 2345 & 215069 & 384 & 85 \\
\hline 2015 & 932 & 821 & 61695 & 93 & 18 & 4859 & 4305 & 399453 & 323 & 231 \\
\hline 2016 & 591 & 499 & 29618 & 79 & 13 & 1460 & 1169 & 106167 & 127 & 164 \\
\hline Total & 11238 & 9755 & 844853 & 848 & 635 & 29001 & 24379 & 2222251 & 1878 & 2744 \\
\hline $\begin{array}{l}\text { Mean } \pm \\
\text { Std Dev }\end{array}$ & $\begin{array}{c}281.0 \pm \\
200.0\end{array}$ & $\begin{array}{c}243.9 \pm \\
179.8\end{array}$ & $\begin{array}{c}21121.3 \pm \\
13911.2\end{array}$ & $\begin{array}{c}21.20 \pm \\
22.7\end{array}$ & $\begin{array}{c}15.9 \pm \\
13.4\end{array}$ & $\begin{array}{c}1035.8 \pm \\
1249.2\end{array}$ & $\begin{array}{l}870.7 \pm \\
1018.6\end{array}$ & $\begin{array}{c}79366.1 \pm \\
93792.3\end{array}$ & $\begin{array}{c}67.1 \pm \\
128.4\end{array}$ & $\begin{array}{c}98.0 \pm \\
180.0\end{array}$ \\
\hline
\end{tabular}


TABLE 2

Correlation of registered, predated and poached nests and the course of time (years) for Santuario Playa Ceuta (SPC) during 1976-2016 and for Playa Caimanero (PC) during 1989-2016

\begin{tabular}{llcccccc}
\hline & \multicolumn{3}{c}{ Santuario Playa Ceuta } & \multicolumn{3}{c}{ Playa Caimanero } \\
\cline { 3 - 8 } & $\begin{array}{c}\text { Registered } \\
\text { nest }\end{array}$ & $\begin{array}{c}\text { Predated } \\
\text { nests }\end{array}$ & $\begin{array}{c}\text { Poached } \\
\text { nests }\end{array}$ & $\begin{array}{c}\text { Registered } \\
\text { nest }\end{array}$ & $\begin{array}{c}\text { Predated } \\
\text { nests }\end{array}$ & $\begin{array}{c}\text { Poached } \\
\text { nests }\end{array}$ \\
\hline Years & rho Spearman & 0.850 & 0.454 & 0.145 & 0.677 & 0.789 & 0.673 \\
& P value & $\leq 0.01$ & 0.003 & 0.372 & $\leq 0.01$ & $\leq 0.01$ & $\leq 0.01$ \\
\hline
\end{tabular}

rho $=$ Spearman's correlation coefficient, $\mathrm{P}<0.05$.

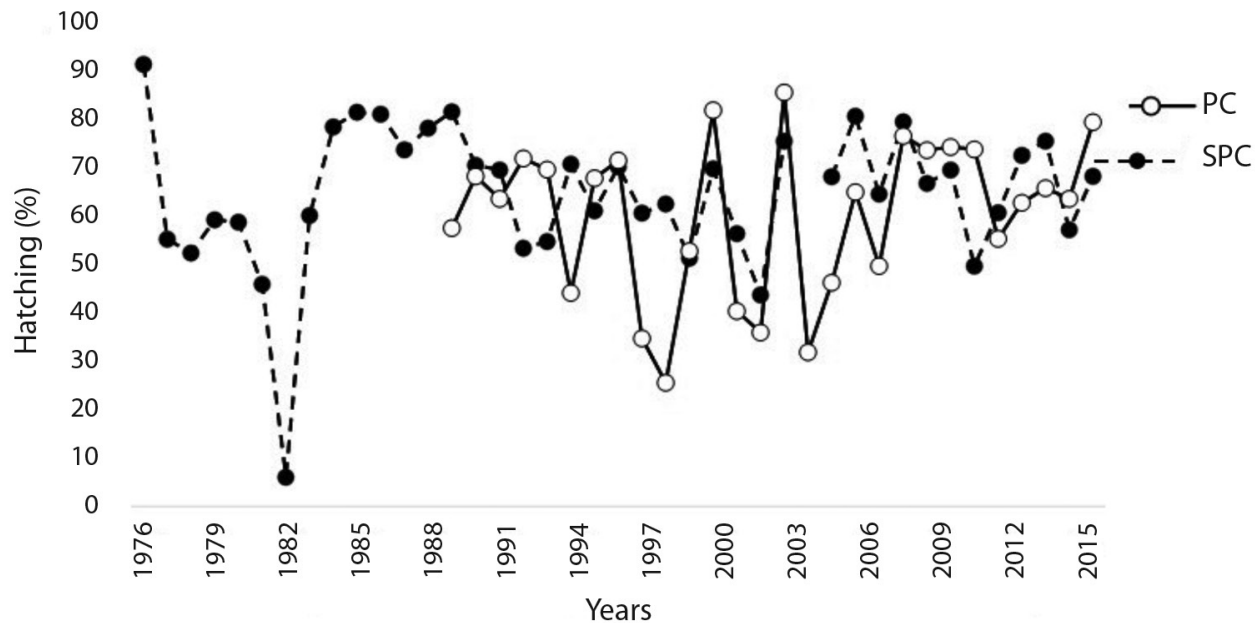

Fig. 2. Annual hatching success of the olive ridley turtle at Santuario Playa Ceuta and Playa Caimanero, Sinaloa, Mexico. SPC: Santuario Playa Ceuta; PC: Playa Caimanero.

for $\mathrm{SPC}$, rho $=0.789, \mathrm{P} \leq 0.01$ for PC, Table 2). The average number of poached nests at SPC was $15.9 \pm 13.4$ nests/year (Table 1). A positive and significant correlation between the number of poached nests $(98.0 \pm 180.0$ nests/year $)$ and time was observed $(\mathrm{rho}=0.673, \mathrm{P}=0.01$; Table 2) for only PC.

Hatching success: HS showed great variability over the years at both beaches. However, since 2009, these oscillations stabilized for both beaches (Fig. 2). HS percentages of $65.09 \pm 14.72 \%$ for SPC and $60.72 \pm 16.39 \%$ for PC were estimated, and these values were not statistically significant between beaches (Mann-Whitney $\mathrm{U}=486, \mathrm{P}=0.360$ ).

Prospective nesting in 2045: According to the annual data analyzed, a predictive time-series model with Brown exponential smoothing was constructed; in both cases, the residual values were independent $(\mathrm{DF}=17$, Ljung-Box Q $(18)=9.492, \mathrm{P}=0.924$ for $\mathrm{SPC}$; $\mathrm{DF}=17$, Ljung-Box $\mathrm{Q}(18)=6.498, \mathrm{P}=0.989$ for $\mathrm{PC}$ ). The observed values have annual variations but suggest a positive trend, as shown by the adjusted values for both beaches (Fig. 3A, Fig. 3B). From a stationary $\mathrm{R}^{2}$ of 0.649 , the prediction for 2045 is 1733 [ -215 , 3 681] nests at SPC (Fig. 3A) and 7718 [-2 435,17871 ] nests at $\mathrm{PC}$, with a stationary $\mathrm{R}^{2}$ of 0.632 (Fig. 3B).

\section{DISCUSSION}

Due to the management and conservation efforts of PROTORMAR-UAS for the olive 

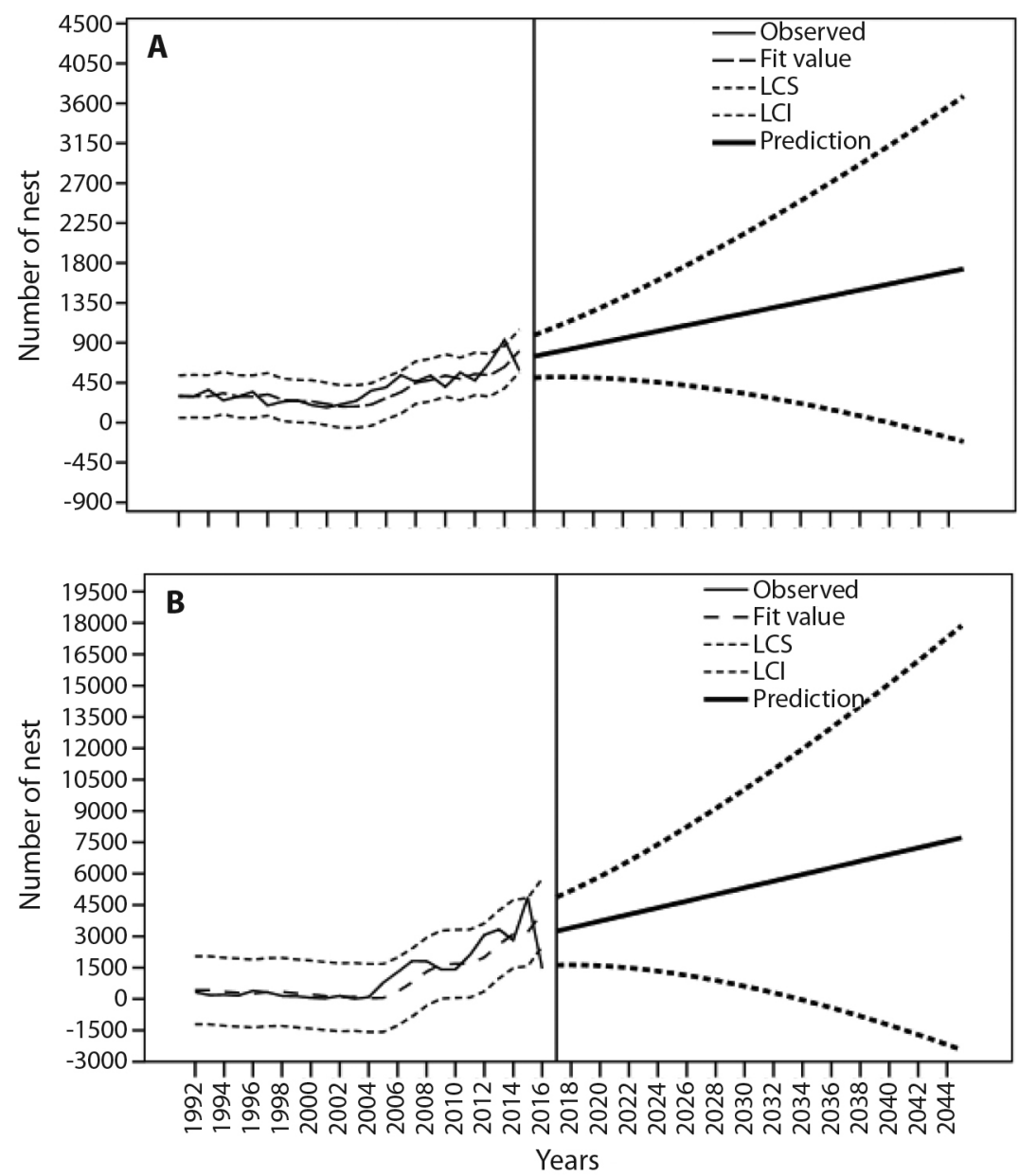

Fig. 3. Time-series predictive model for Lepidochelys olivacea nesting in A. Santuario Playa Ceuta and B. Playa Caimanero, Sinaloa, Mexico, for the year 2045. LCS: superior confidence limit; LCI: inferior confidence limit.

ridley sea turtle in Northwestern Mexico, an increase in the abundance of nests and eggs collected at both biological stations was observed from the start of operation until the last data point. According to the correlation analysis, there was an increase in the number of nests throughout the study period at both beaches. These increases may be due to different causes or even a combination of several factors, which together could influence the observed positive trend of the increase in nests $(\mathrm{rho}=0.850$ and rho $=0.677)$. These values coincide with that reported in Playa La Flor in Nicaragua, where a positive trend was observed over 8 years of monitoring (Honarvar et al., 2016). Increases in the numbers of nests were recorded at both nesting beaches, which have similar lengths $(\approx$ $37 \mathrm{~km}$ ), and the projection for 2045 was positive according to the time-series model with Brown exponential smoothing. At both nesting beaches, monitoring and tours were standardized in 1992; in both cases, initial tours were by foot and later by quad bike, depending on the budget, available staff, and number of volunteers, as well as weather conditions. The current results are in accordance with those reported by Anzanza-Ricardo et al. (2015), who noted that in sea turtle conservation programs, 
resource management is crucial to achieve an adequate cost-benefit balance, and Hart et al. (2018), who stated that an increase in and consolidation of conservation and monitoring activities will result in an increase in the number of nests. However, monitoring and conservation program evaluation continue to be a challenge due to complications that can occur during data collection and difficulty in obtaining financial incentives to promote community participation that promote positive attitudes towards conservation and consistency in the collection of information (Godley et al., 2020).

It is important to emphasize that although there have been increases in the numbers of nests on both beaches after effort standardization, there has been a larger increase at PC, with more than 1000 nests, which is approximately 3 -fold the number of nests than at SPC after 2005. The conditions of both beaches are quite different; SPC is a very spatiotemporally dynamic beach in its granulometry and slope (Sosa-Cornejo et al., 2019), while the conditions at PC are more static. In addition, SPC is in the Nearctic zone, and PC is in the Neotropical zone. The El Verde Camacho nesting beach, also in Sinaloa, has been considered the Northern limit of nesting of the olive ridley turtle in the Mexican Pacific (Ríos-Olmeda, 2005). However, SPC is located at a more Northern latitude, and PC, which is South of El Verde Camacho, has registered a larger number of nests in the last 15 years than the El Verde Camacho nesting site (Contreras-Aguilar, pers. comm.). Genetic analysis of organisms inhabiting SPC indicated that this rockery has moderate genetic diversity that is very similar $(\mathrm{h}=$ 0.6) to that reported by Briseño-Dueñas (1998) for El Verde Camacho (Campista-León et al., 2019); therefore, the importance of monitoring and conserving SPC and the need for more studies at PC are highlighted due to the increasing numbers of nests. In addition, climatic variations, such as the El Niño Southern Oscillation (ENSO), can influence the reproductive success of sea turtles (Santidrián Tomillo et al., 2020); these climatic variations could have no effect or a moderate effect on olive ridley turtle nesting (Ariano-Sánchez et al., 2020; Santidrián Tomillo et al., 2020). This was observed during the extreme El Niño 2015-2016 event, which resulted in decreases in the numbers of nests on both beaches.

Additional factors that may have also influenced the increases in the number of nests are the age at sexual maturity (approximately 13 years [8-18 years]) of age (Márquez, 1996; Zug et al., 2006), the total and permanent ban of the capture of all species of sea turtles in waters under Mexican jurisdiction (DOF, 1990) and the use of sea turtle excluders since 1996 (DOF, 1996). Increases in nesting activity have been reported for other species of sea turtles, such as green and loggerhead turtles (Moncada et al., 2014). Whether the main cause of the increase in the number of nests is increased monitoring effort, the total and permanent capture ban in 1990, spatial changes in the nesting behavior of the olive ridley sea turtle as a result of adaptation to environmental factors, or a combination of these and other factors remains unknown; therefore, it is necessary to carry out additional studies and continue monitoring the abundance of nests in this region. Nesting of olive ridley sea turtles, although sporadic, has been reported in the upper Gulf of California in San Carlos, El Desemboque, and Puerto Peñasco, Sonora (Seminoff \& Nichols, 2007). A record number of olive ridley sea turtle hatchlings (2 241) was recently reported in Desemboque, Sonora, which is located at a very Northern latitude for olive ridley nesting, where conservation has been performed for more than 20 years (Arellano, 2020).

Although olive ridley turtles are the most abundant sea turtles in the world, information on olive ridley turtles is scarce compared to that for other species (Abreu-Grobois \& Plotkin, 2008). According to the IUCN red list, global olive ridley populations are decreasing, with a total decrease between $30 \%$ and $50 \%$, and it is not known whether this reduction has stopped or if it is reversible (Abreu-Grobois \& Plotkin, 2008). However, at the arribada beach, La Flor de Nicaragua, a drastic increase in the number of nests was reported from 1998 to 2006 
(Honarvar et al., 2016), and at Playa Escobilla, the most important arribada beach in Mexico, sustained recovery was reported (1973-2010) (CONANP, 2011). However, considering the wide pantropical nesting habits of the olive ridley turtle, evaluations on solitary beaches are scarce. In the Mexican Pacific South of our study area, in the states of Jalisco and Nayarit, increases in the numbers of nests were reported and attributed to conservation programs that had been implemented for 29 years (Hart et al., 2018). For a beach in Guatemala, a sustained increase in the number of nests over the course of 16 years was reported (Ariano-Sánchez et al., 2020), while for the Pacific beaches of Costa Rica, clear trends have not been reported (James \& Melero, 2015; Viejobueno Muñoz \& Arauz, 2015). For a beach in Brazil, an increase in the number of olive ridley nests was reported in 10 out of 11 years (da Silva et al., 2007).

Similar HS was recorded at both beaches (65.09 and $60.72 \%$ for SPC and PC, respectively); these values were close to those reported by Bárcenas-Ibarra et al. (2015) for El Verde Camacho (58 \%). Other studies have reported a HS rate ranging between 75 and $85 \%$ (Table $3)$. However, these studies were conducted in more Southern latitudes of the Mexican Pacific, except for the study by da Silva et al. (2007).
A lower HS rate was reported for olive ridley turtles than for other species, such as hawksbill and green sea turtles (Bárcenas-Ibarra et al., 2015); this discrepancy could be because for other species, incubation regularly occurs in situ, while for the olive ridley turtle, nests are artificially incubated or relocated to hatcheries, which affects mortality and HS (Mrosovsky, 1982). However, at an olive ridley nesting beach in Costa Rica, Viejobueno Muñoz and Arauz (2015) reported a HS rate of $61.38 \%$ for in situ nests, while the HS rate for nests relocated to a hatchery was $77.9 \%$ (Table 3 ). It is necessary to compare the HS rates of in situ and relocated nests to guide management decisions, although predation and poaching may limit these analyses for both nesting beaches. Another factor influencing the incidence of HS is temperature, as it has been shown that in some cases, temperature exceeds the pivotal point of embryonic mortality (Rafferty \& Reina, 2014; Sandoval, 2012). In addition, it is important to consider different managementrelated factors, such as losses that occur during monitoring phases on the beaches since these also affect HS but are rarely evaluated.

Regarding the number of predated and poached nests, both indicators were higher at PC than at SPC. These results are not

TABLE 3

Hatching success at different nesting beaches of olive ridley turtle (Lepidochelys olivacea), including Santuario Playa Ceuta and Playa Caimanero

\begin{tabular}{lccc}
\hline \multicolumn{1}{c}{ Author (s) } & Year & Country or region & Hatching success (\%) \\
\hline Galván & 1991 & Jalisco, México & 78.3 \\
Cupul-Magaña \& Aranda-Mena & 2005 & Jalisco, México & 77.8 \\
da Silva et al. & 2007 & Sergipe and Bahía, Brasil & 78.7 \\
Bárcenas-Ibarra \& Maldonado Gasca & 2009 & Nayarit, México & 79.4 \\
Barrientos-Muñoz et al. & 2014 & Playa El Valle, Colombia & 81.1 \\
Bárcenas-Ibarra et al. & 2015 & Sinaloa, México. & 58 \\
James \& Melero & 2015 & Península de Osa, Costa Rica & 79.2 \\
Viejobueno Muñoz \& Arauz & 2015 & Punta Banco, Costa Rica & 77.9 \\
Carretero-Morales et al. & 2018 & Jalisco, México & 79.7 \\
Hart et al. & 2018 & Nayarit, Jalisco, México & 85.4 \\
This study SPC & 2016 & Sinaloa, México & 65.08 \\
This study PC & 2016 & Sinaloa, México & 60.72 \\
\hline
\end{tabular}

SPC: Santuario Playa Ceuta; PC: Playa Caimanero. 
surprising, as PC has a higher annual density of nests than SPC, resulting in a greater availability of eggs for predators. Leighton et al. (2010) suggested that the probability of nests being predated or poached increases over time, which was in accordance with the results of the regression analysis for PC. The rate of poaching of eggs at SPC did not increase over time; this is likely because this beach is legally protected and far from urban settlements. PC is not legally protected, and coastal communities are present along the beach, which facilitates poaching even though it is prohibited. Moreover, protection of the beach has not been increased due to the lack of economic resources, and protection status is an important variable for monitoring (García et al. 2003). On Venezuela's nesting beaches, both predation and poaching rates were reduced over 10 years of conservation (2003-2012) (Balladares \& Dubois, 2014). However, each nesting beach and its surrounding environment have very peculiar characteristics. Coyotes (Canis latrans) are the most common opportunistic predators of sea turtles in arid areas of Mexico, and at both SPC and PC, the predation of eggs by coyotes is common; in recent years, the population of this predator has been increasing (Álvarez-Castañeda, 2000; Méndez-Rodríguez \& Álvarez-Castañeda, 2016). At SPC, in addition to coyotes, the presence of new predators such as raccoons and badgers has been reported in recent years (2013-2016), and this may be an explanation for the increase in predation. The presence of these predators could be related to the modification of habitats for shrimp farming and agriculture.

Monitoring and conservation efforts for the olive ridley turtle by the PROTORMARUAS program have indicated that there has been an increase in the number of nests at both beaches since the establishment of the camps to the present day. We suggest that PC, which is located on the latitudinal limit of olive ridley nesting, be designated as a legally protected nesting area, given the need for resources for the operation of the camp to ensure that nest numbers continue to increase and address predation and poaching. In addition, it is necessary to carry out additional studies related to the sex ratio of neonates, management and conservation program success, and mortality and congenital malformation incidence in this species. With this information and data from assessments of nesting trends, it will be possible to identify indicators and form a clearer picture of the situation the olive ridley sea turtle with regard to management and conservation programs to guide appropriate decisions regarding these programs.

Ethical statement: the authors declare that they all agree with this publication and made significant contributions; that there is no conflict of interest of any kind; and that we followed all pertinent ethical and legal procedures and requirements. All financial sources are fully and clearly stated in the acknowledgements section. A signed document has been filed in the journal archives.

\section{ACKNOWLEDGMENTS}

Thanks to the Autonomous University of Sinaloa (UAS) for the continuous financial support for the operation of the Sea Turtle Program (PROTORMAR-UAS); as well as students and staff of the Faculty of Biology and Marine Sciences of UAS. Thanks to the National Commission of Protected Areas (CONANP), and the people of the communities of Ceuta and $\mathrm{La}$ Guasima, Sinaloa who participated during the monitoring of this extensive study. Thanks also to the companies Maricultura del Pacífico and Agrícola Tarriba (Farmers Best) for the sponsorship of equipment and materials.

\section{RESUMEN}

\begin{abstract}
Tendencias de anidación de la tortuga golfina Lepidochelys olivacea (Testudinata: Cheloniidae) en dos playas del noroeste de México después de 30 y 40 años de conservación
\end{abstract}

Introducción: A pesar de que las tortugas golfinas (Lepidochelys olivacea) son las tortugas marinas más abundantes del mundo, su información cuantitativa disponible es 
escasa y se encuentra distribuida de manera desigual entre regiones. Existen muchos programas de manejo y conservación para esta especie, y sus evaluaciones son necesarias para identificar tendencias de anidación y poder manejar de manera efectiva los programas de conservación actuales. PROTORMAR-UAS es un programa de Investigación y Conservación de la tortuga golfina creado por la Universidad Autónoma de Sinaloa, México. El Programa cuenta con dos estaciones biológicas: Santuario de Playa Ceuta (SPC) y Playa Caimanero (PC).

Objetivo: Evaluar la tendencia de anidación de la tortuga golfina en dos playas del noroeste de México y predecir las tendencias prospectivas de anidación para los próximos 30 años.

Métodos: A partir de los datos de registros anuales de anidación de 40 años para SPC (1976-2016) y 30 años para PC (1986-2016), evaluamos las tendencias de anidación, el éxito de la eclosión y los problemas de depredación y saqueo de nidos de la tortuga golfina en las dos playas del noroeste de México. Posteriormente, se calcularon las estimaciones prospectivas de anidación para los próximos 30 años usando un modelo predictivo de series de tiempo. Resultados: Se identificó una correlación positiva y significativa entre el registro anual de nidos y el tiempo de estudio para ambas playas ( $r$ o $=0.850, \mathrm{P} \leq 0.01$ para $\mathrm{SPC}$; rho $=0.677$ y $\mathrm{P} \leq 0.01$ para $\mathrm{PC}$ ); así como el éxito de eclosión promedio de 65.09 para SPC y de $60.72 \%$ para PC. El modelo predictivo de series de tiempo indicó que las anidaciones continuarán aumentando para el 2045, tres veces para SPC y seis para PC, con respecto al último año de monitoreo.

Conclusiones: Hay una clara tendencia positiva de anidación de la tortuga golfina en ambos sitios, lo cual es consistente con la tendencia observada en otros estudios recientes de la región. Por lo tanto, sugerimos incluir a PC como un área de anidación legalmente protegida, la cual se ubica en los límites latitudinales de anidación de la tortuga golfina, dada la necesidad de contar con recursos disponibles para la operación del campamento ante el aumento de anidaciones y de problemas de depredación y saqueo. Porque en México operar una playa de anidación sin ningún estatus de protección implica no tener presupuesto para su manejo.

Palabras clave: nidos; conservación de tortugas marinas; tortuga golfina; éxito de eclosión; saqueo; depredación.

\section{REFERENCES}

Abreu-Grobois, A., \& Plotkin, P. (2008). Lepidochelys olivacea. (The IUCN Red List of Threatened Species, Database, Version 2014.2). IUCN SSC Marine Turtle Specialist Group. https://dx.doi.org/10.2305/IUCN. UK.2008.RLTS.T11534A3292503.en

Álvarez-Castañeda, S. T. (2000). Familia Canidae. In S. T. Álvarez-Castañeda, \& J. L. Patton (Eds.), Mamiferos del Noroeste de México II (pp. 690-705). Centro de
Investigaciones Biológicas del Noroeste, La Paz, Baja California Sur México.

Arellano, A. (2020, 31 Octubre). El milagro de las tortugas marinas en el Desemboque de los Seris. Cobertura360. https://cobertura360.mx/2020/10/31/sonora/ el-milagro-de-las-tortugas-marinas-en-el-desemboque-de-los-seris

Ariano-Sánchez, D., Muccio, C., Rosell, F., \& Reinhardt, S. (2020). Are trends in Olive Ridley sea turtle (Lepidochelys olivacea) nesting abundance affected by El Niño Southern Oscillation (ENSO) variability? Sixteen years of monitoring on the Pacific coast of northern Central America. Global Ecology and Conservation, 24(2020), e01339. https://doi. org/10.1016/j.gecco.2020.e01339

Azanza-Ricardo, J., Gerhartz-Muro, J. L., Martín-Viaña, F., \& Moncada-Gavilán, F. (2015). Efectividad del monitoreo de la anidación de tortugas marinas para determinar el éxito reproductivo en playas del sur de Cuba. Latin American Journal of Aquatic Research, 43(3), 548-556. 10.3856/vol43-issue3-fulltext-16

Balazs, G. H., \& Chaloupka, M. (2006). Recovery trend over 32 years at the Hawaiian green turtle rookery of French Frigate Shoals. Atoll Research Bulletin, $543,147-158$.

Balladares, C., \& Dubois, E. (2014). Saqueo y depredación de nidadas de tortugas marinas, durante las temporadas 2003 a 2012, en seis playas del Golfo de Paria, Venezuela. UNED Research Journal, 6(2), 239-243. http://dx.doi.org/10.22458/urj.v6i2.630

Bárcenas-Ibarra, A., de la Cueva, H., Rojas-Lleonart, I., Abreu-Grobois, F. A., Lozano-Guzmán, R. I., Cuevas, E., \& García-Gasca, A. (2015). First Approximation to congenital malformation rates in embryos and hatchlings of sea turtles. Birth Defects research. Part A, Clinical and Molecular Teratology, 103(3), 203-224.

Bárcenas-Ibarra, A., \& Maldonado Gasca, A. (2009). Malformaciones en embriones y neonatos de tortuga golfina (Lepidochelys olivacea) en Nuevo Vallarta, Nayarit, México. Veterinaria México, 40(4), 371-380.

Barrientos-Muñoz, K. G., Ramirez-Gallego, C., \& Paez, V. (2014). Nesting ecology of the olive ridley sea turtle (Lepidochelys olivacea) (Cheloniidae) at El Valle Beach, Northern Pacific, Colombia. Acta Biológica Colombiana. 19(3), 437-445. http://dx.doi. org/10.15446/abc.v19n3.42457

Behera, S., Tripathy, B., Sivakumar, K., Choudhury, B. C., \& Pandav, B. (2016). Fisheries impact on breeding of olive ridley turtles (Lepidochelys olivacea) along the Gahirmatha coast, Bay of Bengal, Odisha, India. Herpetological Journal, 26(2), 93-98.

Briseño-Dueñas, R. (1998). Variación genética en la región control del ADN mitocondrial de poblaciones de la 
tortuga golfina (Lepidochelys olivacea) en el Pacifico oriental y las implicaciones para su conservación (Tesis de Maestría). Universidad Autónoma de Sinaloa, México.

Brown, R., Durbin, J., \& Evans, J. (1975). Techniques for testing the constancy of regression relationships over time. Journal of the Royal Statistical Society, Series B (Methodological), 37(2), 149-192. https:// doi.org/10.1111/j.2517-6161.1975.tb01532.x

Campista-León, S., Beltrán Espinoza, J. A., Sosa Cornejo, I., Castillo Ureta, H., Martín del Campo Flores, J. R., Sanchez Zazueta, J. G., \& Peinado Guevara, L. I. (2019). Haplotypic characterization of the olive ridley turtle (Lepidochelys olivacea) in northwest Mexico: the northernmost limit of its distribution. Animal Biodiversity and Conservation, 42(1), 113126. https://doi.org/10.32800/abc.2019.42.0113

Carretero-Morales, R. E., Trejo-Robles, J. A., Trejo-Carretero, V., Rodríguez-Plasencia, J. M., Espino-Herrera, A., Estopin-Robles, A. A., Barriga-Vázquez, A. F., Sánchez-Navarro, C., Estrada-Galaviz, J., \& Mosqueda-Chavez, D. (2018). Eclosión en nidos de tortuga golfina Lepidochelys olivacea, Eschscholtz (1829). Campamento Tortuguero "La Gloria", Santuario Playon de Mismaloya Jalisco. En J. Sosa Ramírez, C. Jiménez Sierra, A. B. Solís-Cámara, P. Cortés-Calva, L. Jiménez, E. Barba, S. Y. Alzaga, M. Pinkus, H. González, G. Rodríguez, M. Pinkus, I. C. Espitia, V. M. Martínez, \& A. Ortega (Eds.), LIBRO DE COMUNICACIONES 2do Congreso Internacional de Áreas Naturales Protegidas Aguascalientes, Aguascalientes 2018 (pp. 241-242). Universidad Autónoma de Aguascalientes, México.

Caut, S., Guirlet, E., Jouquet, P., \& Girondot, M. (2006). Influence of nest location and yolkless eggs on the hatching success of leatherback turtle clutches in French Guiana. Canadian Journal of Zoology, 84(6), 908-915. https://doi.org/10.1139/Z06-063

Ceriani, S. A., Casale, P., Brost, M., Leone, E. H., \& Witherington, B. E. (2019). Conservation implications of sea turtle nesting trends: elusive recovery of a globally important loggerhead population. Ecosphere, 10(11), e02936. https://doi.org/10.1002/ecs2.2936

CONANP (2011). Tortuga golfina. Comisión Nacional de Áreas Naturales Protegidas. http://procer.conanp.gob. $\mathrm{mx} /$ tortugas/sitio/odf/fichas_tortugas/tortuga_golfina_2011.pdf

CONANP (2018). Ficha SIMEC (Sistema de Información, Monitoreo y Evaluación para la Conservación) del Santuario Playa Ceuta, Elota, Sinaloa. Comisión Nacional de Áreas Naturales Protegidas. https:// simec.conanp.gob.mx/ficha.php?anp=11\&=11

Convention on International Trend in Endangered Species of Wild Fauna and Flora (CITES) (2014). Appendices I, II and III. http://www.cites.org/eng/app/appendices.php.
Cupul-Magaña, F. G., \& Aranda-Mena, O. S. (2005). Éxito de eclosión del cocodrilo americano (Crocodylus acutus) y la tortuga golfina (Lepidochelys olivacea) en Puerto Vallarta, Jalisco, México. Revista Electrónica de Veterinaria, 6(10), 1-7.

da Silva, A. C., de Castilhos, J. C., López, G. G., \& Barata, P. C. R. (2007). Nesting biology and conservation of the olive ridley sea turtle (Lepidochelys olivacea) in Brazil, 1991/1992 to 2002/2003. Journal of the Marine Biological Association of the United Kingdom, 87(4), 1047-1056. https://doi.org/10.1017/ S0025315407056378

Diario Oficial De La Federación (1986). DECRETO por el que se determinan como zonas de reserva y sitios de refugio para la protección, conservación, repoblación, desarrollo y control, de las diversas especies de tortuga marina, los lugares en que anida y desova dicha especie. Gobierno Federal de México. http:// dof.gob.mx/nota_detalle.php?codigo $=4815894 \&$ fec ha $=29 / 10 / 1986$

Diario Oficial De La Federación (1990). ACUERDO por el que se establece veda para las especies y subespecies de tortuga marina en aguas de jurisdicción Federal del Golfo de México y Mar Caribe, así como en las costas del Océano Pacífico, incluyendo el Golfo de California. Diario Oficial de la Federación. Gobierno Federal de México. http://www.dof.gob.mx/nota_detalle. php? codigo $=4658226 \&$ fecha $=31 / 05 / 1990$

Diario Oficial De La Federación (1996). Norma Oficial Mexicana de Emergencia 001-PESC-1996, por la que se establece el uso obligatorio de los dispositivos excluidores de tortugas marinas en las redes de arrastre camaroneras durante las operaciones de pesca de camarón en el Océano Pacífico, incluyendo el Golfo de California. Gobierno Federal de México. http:// www.dof.gob.mx/nota detalle.php? codigo $=4875991$ \&fecha $=18 / 03 / 1996$

Diario Oficial De La Federación (2002). ACUERDO por el que se determinan como áreas naturales protegidas, con la categoría de santuarios, a las zonas de reserva y sitios de refugio para la protección, conservación, repoblación, desarrollo y control de las diversas especies de tortuga marina, ubicadas en los estados de Chiapas, Guerrero, Jalisco, Michoacán, Oaxaca, Sinaloa, Tamaulipas y Yucatán, identificadas en el decreto publicado el 29 de octubre de 1986. Gobierno Federal de México. https://www.dof.gob.mx/nota detalle.php? codigo $=723470 \&$ fecha $=16 / 07 / 2002$

Diario Oficial De La Federación (2010). Protección Ambiental de Especies Nativas de México de Flora y Fauna Silvestres. Categorías de riesgo y especificaciones para la inclusión, exclusión o cambio de listas de especies en riesgo (Norma Oficial Mexicana NOM-059-SEMARNAT-2010). Gobierno Federal de México. https://dof.gob.mx/nota_detalle_popup. php? codigo $=5173091$ 
Frazier, J. (2003). Prehistoric and ancient historic interactions between humans and marine turtles. In P. L. Lutz, J. A. Musick, \& J. Wyneken (Eds.), The biology of sea turtles, Volume II (pp. 1-38). CRC Press. https://doi.org/10.1201/9781420040807

Galván, P. V. (1991). Estudio de la Mortalidad Embrionaria de Lepidochelys olivacea en nidos incubados seminaturalmente en playas de Mismaloya, Jalisco, México (Tesis de Licenciatura). Universidad de Guadalajara, México.

García, A., Ceballos, G., \& Adaya, R. (2003). Intensive beach management as an improved sea turtle conservation strategy in Mexico. Biological Conservation, 111(2), 253-261. https://doi.org/10.1016/ S0006-3207(02)00300-2

Gil, G. E., \& Lobo, J. M. (2012). El uso de modelos predictivos de distribución para el diseño de muestreos de especies poco conocidas. Mastozoología Neotropical, 19(1), 47-62. https://www.redalyc.org/articulo. oa? id $=457 / 45723408005$

Godley, B. J., Broderick, A. C., Colman, L. P., Formia, A., Godfrey, M. H., Hamann, M., Nuno, A., Omeyer, L. C. M., Patricio, A. R., Phillot, A. D., Rees, A. F., \& Shanker, K. (2020). Reflections on sea turtle conservation. Oryx, 54(2020), 287-289. https://doi. org/10.1017/S0030605320000162

Hart, C. E., Maldona-Gasca, A., Ley-Quiñonez, C. P., Flores-Peregrina, M., Romero-Villarruel, J., ArandaMena, O. S., Plata-Rosas, L. J., Tena-Espinoza, M., Llamas-González, I., Zavala-Norzagaray, A., Godley, B. J., \& Abreu-Grobois, F. A. (2018). Status of Olive Ridley Sea Turtles (Lepidochelys olivacea) After 29 Years of Nesting Rookery Conservation in Nayarit and Bahía de Banderas, Mexico. Chelonian Conservation and Biology, 17(1), 27-36. https://doi. org/10.2744/CCB-1255.1

Honarvar, S., Brodsky, M. C., Van Den Berghe, E. P., O’Connor, M. P., \& Spotila, J. R. (2016). Ecology of Olive Ridley sea turtles at arribadas at playa La Flor, Nicaragua. Herpetologica, 72(2016), 303-308. https://doi.org/10.1655/Herpetologica-D-16-00014.1

James, R., \& Melero, D. (2015). Anidación y conservación de la tortuga lora (Lepidochelys olivacea) en playa Drake, península de Osa, Costa Rica (2006 a 2012). Revista de Biología Tropical, 63, 117-129. http:// dx.doi.org/10.15517/rbt.v63i1.23099

Leighton, P. A., Horrocks, J. A., \& Kramer, D. L. (2010). Predicting nest survival in sea turtles: when and where are eggs most vulnerable to predation? Animal Conservation, 14(2), 186-195. https:/doir. org/10.1111/j.1469-1795.2010.00422.x

Márquez, R. (1990). Sea turtles of the world, an annotated and illustrated catalogue of sea turtle species known to date. Food and Agriculture Organization. http:// www.fao.org/3/t0244e/t0244e00.htm
Márquez, R. (1996). Las tortugas marinas y nuestro tiempo. La ciencia desde México, serie el océano y sus recursos. Fondo de Cultura Económica.

Méndez-Rodríguez, L., \& Álvarez-Castañeda, S. T. (2016). Predation on turtle nests in the southwestern coast of the Baja California Peninsula. Revista Mexicana de Biodiversidad, 87(2), 483-488. http://dx.doi. org/10.1016/j.rmb.2016.02.005

Moncada, F., Tizol, D., Nodarte, G., \& Medina, Y. (2014). Efecto de las vedas en las poblaciones anidadoras de tortuga verde (Chelonia mydas) y caguama (Caretta caretta) en la playa El Guanal, Isla de la Juventud, Cuba. Revista Cubana de Investigaciones Pesqueras, 31(2), 1-6

Mortimer, J. A. (1999). Reducing threats to eggs and hatchlings: hatcheries. In K. L. Eckert, K. A. Bjorndal, F. A. Abreu-Grobois, \& M. Donnelly (Eds.), Research and management techniques for the conservation of sea turtles (pp. 175-178). IUCN/SSC Marine Turtle Specialist Group.

Mrosovsky, N. (1982). Sex ratio bias in hatchling sea turtles from artificially incubated eggs. Biological Conservation, 23(4), 309-314. https://doi. org/10.1016/0006-3207(82)90087-8

Pandav, B., Choudhury, B., \& Shanker, K. (1998). The Olive Ridley sea turtle (Lepidochelys olivacea) in Orissa: An urgent call for an intensive and integrated conservation programme. Current Science, 75(12), 1323-1328. https://www.jstor.org/stable/24101018

Peñaflores, C., Vasconcelos, J., Albavera, E., \& Márquez, R. (2000). Twenty-five years nesting of olive ridley sea turtle Lepidochelys olivacea in Escobilla Beach, Oaxaca, Mexico. In F. A. Abreu-Grobois, R. Briseño, R. Márquez, \& L. Sarti (Eds.), Proceedings of the 18th International Sea Turtle Symposium (pp. 27-29). NOAA Tech Memo NMFS-SEFSC-436, NOAA.

Pritchard, P. C. H. (1996). Evolution, phylogeny and current status. In P. L. Lutz, \& J. A. Musick (Eds.), The Biology of Sea Turtles (pp. 1-28). CRC Press.

Pritchard, P. C. H. (2007). Arribadas I have known. In P. T. Plotkin (Ed.), Biology and Conservation of Ridley Sea Turtles (pp. 7-21). The Johns Hopkins University Press.

Rafferty, A. R., \& Reina, R. D. (2014). The influence of temperature on embryonic developmental arrest in marine and freshwater turtles. Journal of Experimental Marine Biology and Ecology, 450, 91-97. https:// doi.org/10.1016/j.jembe.2013.10.018

Richardson, J. I. (2000). Prioridades para los Estudios sobre la Biología de la Reproducción y de la Anidación. In K. L. Eckert, K. A. Bjorndal, F. A. Abreu-Grobois, \& M. Donnelly (Eds.), Técnicas de investigación y Manejo para la Conservación de 
las Tortugas Marinas (pp. 912). UICN/CSE Grupo Especialista en Tortugas Marinas.

Ríos-Olmeda, D. (2005). Base de Datos (1975-2005). Centro de Protección y Conservación de Tortugas Marinas El Verde Camacho. Mazatlán, Sinaloa. Programa Nacional de Tortugas Marinas, Comisión Nacional de Áreas Naturales Protegidas (CONANPSEMARNAT). México.

Sandoval, S. (2012). Proporción sexual en crías de tortuga Lepidochelys olivacea en corrales de incubación del pacífico mexicano (Tesis de Doctorado). Centro Interdisciplinario de Ciencias Marinas, Instituto Politécnico Nacional, México.

Santidrián Tomillo, P., Fonseca, L. G., Ward, M., Tankersley, N., Robinson, N. J., Orrego, C. M., Paladino, F. V., \& Saba, V. S. (2020). The impacts of extreme El Niño events on sea turtle nesting populations. Climatic Change, 159(2), 163-176. https://doi.org/10.1007/ s10584-020-02658-w

Schoreder, B., \& Murphy, S. (2000). Prospecciones poblacionales (terrestres y aéreas) en playas de anidación. En K. L. Eckert, K. A. Bjorndal, F. A. Abreu-Grobois, \& M. Donnelly (Eds.), Técnicas de Investigación y Manejo para la Conservación de las Tortugas Marinas (pp. 51-63). UICN/CSE Grupo Especialista en Tortugas Marinas.

Seminoff, J. A., \& Nichols, W. J. (2007). Sea turtles of the Alto Golfo: a struggle for survival. In R. S. Felger, B. Broyles (Eds.), Dry Borders, Great Natural Reserves of the Sonoran Desert (pp. 505-518). University of Utah Press.

Sosa-Cornejo, I., Moran-Angulo, R. E., Enciso-Saracho, F., Barraza-Ortega, M. A., Contreras-Aguilar, H., \& Sosa-Pérez, R. (2019). Características físicas y químicas del sustrato arenoso de la zona de anidación de la tortuga marina Lepidochelys olivacea en Playa Ceuta, Sinaloa, Mexico. In E. A Cuevas Flores, V. Guzmán Hernández, J. J. Guerra Santos, \& G. A. Rivas Hernández (Eds.), El Uso del Conocimiento de las Tortugas Marinas como herramienta para la restauración de sus poblaciones y hábitats asociados (pp. 151-160). Universidad Autónoma del Carmen, México.

Spotila, J. (2004). Sea turtles, a complete guide to their biology, behavior, and conservation. The Hopkins University Press.

Viejobueno Muñoz, S., \& Arauz, R. (2015). Conservación y actividad reproductiva de tortuga lora (Lepidochelys olivacea) en la playa de anidación solitaria Punta Banco, Pacífico Sur de Costa Rica. Recomendaciones de manejo a través de dieciséis años de monitoreo. Revista de Biología Tropical, 63, 383-394. http://dx.doi.org/10.15517/rbt.v63i1.23117

Zug, G. R., Chaloupka, M., \& Balazs, G. H. (2006). Age and growth in olive ridley sea turtles (Lepidochelys olivacea) from the North-central Pacific: a skeletochronological analysis. Marine Ecology, 27(3), 263-270. https://doi.org/10.1111/j.1439-0485.2006.00109.x 